DOI: $10.36910 / 6775-2524-0560-2020-38-09$

УДК 004.9:[378.016:811.161.2’243

Пахолок Зінаїда Олександрівна, д.ф.н., професор

https://orcid.org/0000-0002-8911-5909

Луцький інститут розвитку людини Університету «Україна», Луцьк, Україна

Миронюк Лілія Павлівна, к.ф-м.н., доцент

https://orcid.org/0000-0002-4822-659X

Східноєвропейський національний університет ім. Лесі Українки, Луцьк, Україна

\title{
МЕТОДИКА ОПРАЦЮВАННЯ ХМАРНИХ СЕРВІСІВ GOOGLE SLIDES TA SITES ДЛЯ СТВОРЕННЯ ПРЕЗЕНТАЦІЙ ПРО РІДНУ КРАЇНУ І РОЗМІЩЕННЯ ЇХ НА САЙТІ В КУРСІ «УКРАЇНСЬКА МОВА ЯК ІНОЗЕМНА»
}

\begin{abstract}
Пахолок 3. О., Миронюк Л. П. Методика опрацювання хмарних сервісів Google Slides та Sites для створення презентацій про рідну країну і розміщення їх на сайті в курсі «Українська мова як іноземна». На сучасному етапі розвитку освіти в Україні пріоритетним напрямом $є$ впровадження інформаційних технологій. Провідною тенденцією світових інформаційних технологій є хмарні технології віддаленого збереження даних. Оскільки під час іспиту «Українська мова як іноземна» слухачі мають представити презентацію про рідну країну, то було запропоновано вмотивовану модель презентації та іï створення в Google Slides. Сервіс Google Slides обрано на підставі таких характеристик: безкоштовність, простота використання, можливість застосування з будь-якого пристрою за наявності Інтернету, легкий зв'язок чи розміщення документу на веб-сторінці, сумісність користувачів у доступі та редагуванні документів через Інтернет, незалежно від того, на якому пристрої вони працюють; імпорт файлів із Microsoft. Для розміщення важливої та цікавої інформації про країни, в яких проживають слухачі-іноземці, було створено сайт за допомогою Google Sites.

Ключові слова: інформаційно-комунікаційні технології, хмарні сервіси, Google Slides, Google Sites, заклад вищої
\end{abstract} освіти, слухачі-іноземці, українська мова як іноземна, презентація, країнознавство.

Пахолок 3. А., Миронюк Л. П. Методика обработки облачных сервисов Google Slides и Sites для создания презентаций о родной стране и размещения их на сайте в курсе «Украинский язык как иностранный». На современном этапе развития образования в Украине приоритетным направлением является внедрение информационных технологий. Ведущей тенденцией мировых информационных технологий является облачные технологии удаленного хранения данных. Поскольку во время экзамена «Украинский язык как иностранный» слушатели должны представить презентацию о родной стране, то было предложено обоснованную модель презентации и ее создание в Google Slides. Сepвис Google Slides избран на основании следующих характеристик: бесплатность, простота использования, возможность применения с любого устройства при наличии Интернета, легкая связь или размещения документа на веб-странице, совместимость пользователей в доступе и редактировании документов через Интернет, независимо от того, на каком устройстве они работают; импорт файлов из Microsoft. Для размещения важной и интересной информации о странах, в которых проживают слушатели-иностранцы, был создан сайт с помощью Google Sites.

Ключевые слова: информационно-коммуникационные технологии, облачные сервисы, Google Slides, Google Sites, высшее учебное заведение, слушатели-иностранцы, украинский язык как иностранный, презентация, страноведение.

Pakholok Z. O., Myroniuk L. P. Methods of treatment of Google Slides cloud processing services and Sites to make homepage presentations and placing them on the site in the course «Ukrainian language as foreign». The introduction of information technologies that would completely meet the needs of users is the main field at the present stage of education development in Ukraine. The leading trend in the world of information technology is cloud-based remote storage technologies. As students are required to submit a presentation about their home country during the «Ukrainian as a foreign language» exam, a motivated presentation model and its creation in Google Slides have been suggested. The service Google Slides is based on the following features: free, easy to use, accessible from any device on the Internet, easy to access or place a document on a web page, users' compatibility in accessing and editing documents online, notwithstanding what device they work on; import files from Microsoft. A site was created using Google Sites to provide important and interesting information about the countries of foreign listeners residence.

Keywords: information and communication technologies, cloud services, Google Slides, Google Sites, institution of higher education, foreign listeners, Ukrainian as a foreign language, presentation, country studies.

Постановка наукової проблеми. Всі аспекти життя сучасного суспільства охоплені процесом інформатизації. Згідно національної стратегії розвитку освіти в Україні на період до 2021 року, пріоритетним $\epsilon$ впровадження інформаційно-комунікаційних технологій, що забезпечують удосконалення навчально-виховного процесу, доступність та ефективність освіти, підготовку молодого покоління до життєдіяльності в інформаційному суспільстві [7].

До різновидів інформаційно-комунікаційних технологій належать «хмарні технології» або «хмарні обчислення» (cloud computing). Їх концепція з'явилася ще в 1960 році, коли американський учений, фахівець з інформатики і теорії електронно-обчислювальних машин Джон Маккарті (John 
McCarthy) висловив припущення, що у недалекому майбутньому комп'ютерні обчислення стануть надаватися подібно до комунальних послуг (public utility).

Активне використання терміну «хмарні технології» у світі починається 32006 року. Л. С. Черняк вважає, що вперше термін «хмара» вжив та спробував витлумачити генеральний директор компанії Google Ерік Шмідт [11].

В Україні термін «хмарні технології» почали впроваджувати з 2008 року, але під «хмарою»на той час розуміли безкоштовні хостинги поштових служб для студентів та викладачів. Усі інші інструменти, які, зазвичай, пропонували для використання в «хмарі», були відсутні через недостатність інформації та брак навичок використання [8, с. 105].

Адекватного визначення цього терміну не існує й дотепер, оскільки дослідники пропонують власне бачення у контексті певної проблеми. Г. Д. Кисельов і К. В. Харченко подають таку дефініцію: «cloud computing - це програмно-апаратне забезпечення, яке доступно користувачу через Інтернет у вигляді сервісу, який надає зручний інтерфейс для віддаленого доступу до обчислювальних ресурсів (програм і даних)» [4, с. 351]. О. М. Туравініна вважає, що хмарні обчислення - це «технологія опрацювання даних, в яких програмне забезпечення надається користувачеві як Інтернет-сервіс» [9, с. 119]. К. М. Лавріщева й А. Ю. Стеняшин розуміють під хмарними обчисленнями «нові системні засоби для підтримки обчислень, якими є Google Apps, IBM-VSphere та системи Microsoft - WCloud, Azure, Amazon, Mech, WApps, SkyDriven тощо» [5, c. 201]. Згідно з документом Інституту інженерів 3 електротехніки та електроніки (Institute of Electrical and Electronics Engineers, IEEE), «хмарні обчислення - це парадигма, в рамках якої інформація постійно зберігається на серверах у мережі інтернет і тимчасово кешується на клієнтській стороні, наприклад, на персональних комп'ютерах, ігрових приставках, ноутбуках, смартфонах тощо» [10].

Однак більшість вітчизняних та зарубіжних авторів користується точним і універсальним формулюванням Національного Інституту Стандартів та Технологій (The National Institute of Standards and Technology, NIST). Під хмарними обчисленнями розуміється модель зручного мережевого доступу до загального фонду обчислювальних ресурсів (наприклад, мереж, серверів, файлів даних, програмного забезпечення та послуг), які можна швидко надати за умови мінімальних управлінських зусиль та взаємодії з постачальником [12, с. 30-31].

У широкому сенсі хмарні обчислення - це Інтернет-технології віддаленого збереження даних. Хмарний сервіс - послуга надання хмарних ресурсів за допомогою технологій хмарних обчислень. Хмарні технології $є$ однією 3 провідних тенденцій світових інформаційних технологій, а хмарні сервіси в освіті розглядаються як найбільш перспективний розвиток упровадження хмарних технологій. Згідно М. П. Шишкіною та М. В. Попель, «хмарні сервіси широко застосовуються в навчальних закладах України, поряд з цим їх використання не $\epsilon$ систематичним, не організовано в єдину систему, не $є$ достатньо цілеспрямованим і зорієнтованим на певні педагогічні цілі» [13, с. 74].

На сьогодні найбільшими постачальниками програмного контенту для навчальних закладів $\epsilon$ компанії «Microsoft» i «Google», що надають програмні та інфраструктурні сервіси школам, коледжам і університетам. Прикладами сучасних сервісів, побудованих на основі хмарних обчислень для освіти, є Live@edu від Microsoft i Google Apps Education Edition.

Аналіз останніх досліджень і публікацій. Останнім часом багато науковців Т. Л. Архіпова, В. Ю. Биков, Ю. В. Грицук, М. І. Жалдак, Г. Д. Кисельов, Н. Б. Копняк, Г. Р. Корицька, Ю. Г. Носенко, С. О. Семеріков, І. М. Стромило, А. М. Стрюк, М. А. Шиненко та ін. присвячують свої публікації теоретичним та практичним основам застосування хмарних технологій в освіті та навчальній діяльності.

Вагомий внесок в теорію і практику використання хмарних сервісів в освітній процес зробили зарубіжні вчені Х. Ф. Альделейай, К. Р. Аніл Кумар, Р. Гурунатх, Д. Е. Дін, Г. Л. Пратт, К. Хеввіт та iн.

Теоретичні та практичні аспекти використання хмарних сервісів Microsoft Office 365 детально вивчено у дослідженнях науковців Інституту інформаційних технологій та засобів навчання Національної Академії педагогічних наук України С. Г. Литвинової, О. П. Пінчук, О.М.Спіріна, М. П. Шишкіної та ін.

Найбільш зручними й популярними сьогодні є хмарні сервіси Google, об’єднані під єдиним брендом Google Cloud, до якого входять Gmail, Google Docs, Sheets та Slides тощо. Впровадженням сервісів Google в освітній процес займались Н. Р. Балик, А. С. Карпенко, Н. В. Кононец, Н. В. Морзе, М. В. Носкова, В. П. Олексюк, Л. В. Рождественська, О. М. Спірін, М. П. Шишкіна. Досвід інтеграції 
хмарних сервісів Google Apps в інформаційний простір вищого навчального закладу описав В. П. Олексюк, а порівняльні характеристики сервісів Google - О. Д. Гуменний та I. O. Падій.

Інформаційно-комунікаційні технології - неодмінна складова навчання іноземних громадян українській мові в Східноєвропейському національному університеті імені Лесі Українки. Підготовче відділення у найбільшому навчальному закладі Волині з 2010 року закінчили не тільки англомовні та франкомовні громадяни переважно з африканського континенту (Алжир, Гана, Замбія, Зімбабве, Камерун, Лівія, Конго, Намібія, Нігерія, Сенегал, Сирія, Того), але й з Болгарії, Бразилії, Китаю, США.

В основу навчання покладена модель мовленнєвої поведінки носія української мови у сфері щоденного спілкування як орієнтир для іншомовного комуніканта. Методичне забезпечення курсу здійснюється завдяки підручникам «Вступний курс з української мови для студентів-іноземців підготовчого відділення» за редакцією Т. О. Дегтярьової [1] і Т. Є. Масицької «Українська мова як іноземна: Комунікація» [6], а також методичним розробкам Є. І. Гороть, Н. О. Данилюк, Л. К. Малімон, О. О. Рогач [2] та Н. О. Данилюк і Т. Є. Масицької [3], в яких підібрано мовний,

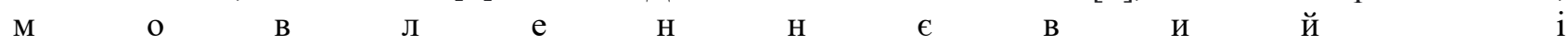
комунікативний матеріал.

Слухачі-іноземці вивчають українську мову не тільки під час аудиторних занять, але і на дозвіллі. Процес соціокультурної адаптації пришвидшують пізнавальні екскурсії. Як правило, перша екскурсія проводиться в університетському музеї Лесі Українки. Відбувається процес інтерактивного навчання, який забезпечує внутрішню мотивацію освіти та сприяє іiї ефективності.

Після закінчення навчання, на випускному іспиті, який проводиться в два етапи, слухачііноземці мають представити розповідь про себе та свою родину, написати диктант, виконати практичне заняття з граматики, прочитати текст і відповісти на питання до нього. Якщо розповідь про свою сім'ю не викликає труднощів у слухачів-іноземців, то презентація про рідну країну є неповною, не дивлячись на попередні настанови викладача.

Мета статті полягає в представленні моделі презентації про рідну країну, створену за допомогою Google Slides для слухачів-іноземців підготовчого відділення Східноєвропейського національного університету ім. Лесі Українки та поширення інформації про неї на сайті Google Sites для перевірки набутих знань української мови.

Мета корелює завдання: запропонувати вмотивовану структуру презентації; вказати на переваги Google Slides перед Power Point; радити працювати 3 Google Slides для створення презентацій; вказати на перспективу використання сайту, створеного засобами Google Sites.

Дослідження проводилося на базі підготовчого відділення Східноєвропейського національного університету імені Лесі Українки. Під час роботи було використано комплекс методів і прийомів: спостереження за виконанням презентацій та їх представленням слухачами-іноземцями; створення моделі для майбутніх презентацій; теоретична і практична підготовка слухачів-іноземців для удосконалення презентації: інструктаж, який включав статистичні дані стосовно кількості слайдів та часу на виступ, ознайомлення з вже існуючими зразками презентацій, пропозиції щодо використання англомовних і українськомовних сайтів, які містять інформацію про рідну країну; звернення уваги на те, що кожен слайд має обов'язково містити коротку текстову інформацію і варто написати додаткову інформацію українською літературною мовою.

Виклад основного матеріалу й обгрунтування отриманих результатів. Досвід роботи із слухачами-іноземцями показав, що для виконання презентації необхідно, перш за все, спиратися на чіткий список слайдів, який дозволить представити країнознавчу інформацію в усій повноті. 3 цією метою ми запропонували слухачам-іноземцям використати метод комплексності, який полягає у всебічній характеристиці конкретної країни. Одна 3 особливостей підходу до країнознавчого матеріалу криється в намаганні охопити всі сторони об'єкта представлення. Наші випускники мають виступити у ролі збирачів, зберігачів і ретрансляторів даних про географію, сучасну історію, політичний розвиток, економіку, культуру рідної країни, усвідомлюючи важливість інформаційної функції країнознавства.

У процесі дослідження ми дійшли висновку, що оптимальним варіантом 3 точки зору інформативності є наступний перелік слайдів.

1. Країна (назва на фоні прапора).

2. Герб і девіз країни. 
3. Назва гімну та музичні інструменти для його виконання.

4. Мапа континенту (збоку кількість населення).

5. Мапа країни (збоку кількість населення).

6. Столиця країни, кількість населення в місті.

7. Політичний і державний устрої країни. Валюта.

8. Президент (ім’я і прізвище, рік народження).

9. Мови та етнічні групи.

10. Традиційне вбрання чоловіків.

11. Традиційне вбрання жінок.

12. Прикраси.

13. Видатні особистості країни (від початку державності до сьогодення, ім'я і прізвище, рік народження):

політичний діяч (суспільний діяч), з яким асоціюється країна,

вчений,

письменник,

артист (актор, співак, художник),

спортсмен.

14. Визначні локації в місті.

15. Визначні локації поза містом.

16. Принада для мандрівників.

17. Національна кухня (вказати інгредієнти):

іжа,

напої.

18. Природні ресурси.

19. Економічні ресурси.

20. Заключний слайд з фото автора (Дякую за увагу!).

Сукупність слайдів не має перевищувати 30-35, а тривалість демонстрації 40-60 хвилин, враховуючи специфіку країни й додаткову текстову інформацію, яку виголошує випускник.

На екзамені слухач-іноземець повинен продемонструвати вміння користуватися інформаційноаналітичною, комунікативною і репрезентативною функціями при викладенні матеріалу українською літературною мовою.

Під час виконання презентацій були непоодинокими випадки, коли слухачі не мали комп'ютера чи ноутбука 3 необхідним програмним забезпеченням, а використовували смартфон чи айфон. Ця обставина спонукала до пошуків нової домінанти серед сервісного програмного забезпечення Microsoft та найбільш популярного в світі пошуковика - Google. Обидва конкуренти виступили на ринку хмарних сервісів, де лідером уже впродовж багатьох років є Amazon.

Якщо раніше популярним був Microsoft PowerPoint, згідно даних публічного web-додатку Google Trends, який показує, як часто термін шукають по відношенню до загального обсягу пошукових запитів різними мовами у різних регіонах світу, то згодом в умовах жорсткої конкуренції популярність його знизилась, поступившись відносно новим презентаціям Google Slides.

Microsoft PowerPoint входить до складу платного хмарного сервісу Office 365, a Східноєвропейський національний університет імені Лесі Українки підключений до нього. Оскільки слухачі-іноземці не є студентами навчального закладу, то для них не можуть бути створені облікові записи в Office 365 .

При виборі додатку, необхідного випускникам для створення презентації, ми також керувалися наступними міркуваннями: безкоштовність, простота застосування, зберігання у віртуальному файлменеджері, швидкий доступ, наявність інтеграції з іншими додатками, відсутність необхідності в офісних пакетах, можливість ділитися проміжними результатами 3 колегами та слухачами, в нашому випадку - викладачами, навіть за умов використання різних операційних систем.

Додаток Google Slides пропонує ряд інтуїтивних та інноваційних функцій презентації. В ньому доступні основні функції з оформлення презентацій, кілька шаблонів дизайну, різноманітні шрифти, анімаційні ефекти та інші інструменти.

Усі зазначені вище причини привели до вибору хмарного сервісу Google Slides.

Проаналізувавши можливості презентацій Google Slides, можна навести основні їх риси: 
- сервіси Google в цілому, а також Google Slides, зокрема, є безкоштовними;

- простота використання, можливість застосування файлів-довідок;

- робота з Google Slides на будь-якому пристрої за наявності Інтернету;

- інтегрування в інші додатки Google;

- одночасна робота з Google Slides незалежно від пристрою, на якому працюють користувачі (іноземець-слухач, викладач української мови та викладач інформатики);

- сумісність з Microsoft PowerPoint.

Проте Google Slides має й ряд недоліків:

- необхідність забезпечення постійного з’єднання з мережею Інтернет;

- відсутність технологій гарантування збереження та конфіденційності даних;

- кількість ефектів є приблизно 15 (в Microsoft PowerPoint - приблизно 50);

- можливість імпорту лише відео YouTube (Microsoft PowerPoint імпортує аудіофайли);

- наявність облікового запису Gmail.

Варто підкреслити, що створену презентацію слухачі-іноземці можуть роздрукувати, надіслати поштою чи опублікувати в Інтернеті, зберегти на локальному комп'ютері, причому доступними $\epsilon$ декілька варіантів збереження, в тому числі й Microsoft PowerPoint (з розширенням .pptx). Завдяки цьому викладачі здійснюють перевірку, звертаючи увагу на композицію розташування зображення $\mathrm{i}$ тексту та правильність написів.

Після цього викладач інформатики розміщує нову країнознавчу інформацію на сайті, створеному за допомогою Google Sites.

Вибір цього сервісу обумовлений низкою причин, оскільки, по-перше, Google Sites дозволяє безкоштовно створювати повноцінні веб-сторінки 3 використанням вікі-технології. По-друге, розміщувати сайти у мережі Інтернет. По-третє, уможливлює доступ до роботи над сайтом декількох користувачів, в нашому випадку - викладачів.

Зауважимо відразу, що безкоштовний хостинг від Google Sites регулюється такими вимогами:

- обсяг дискового простору - до 100 Мб для зберігання інформації на сайті й 10 Гб на кожен домен для зберігання інформації при використанні Google Служб;

- не підтримуються CSS i JavaScript;

- доменне ім'я сайту має вигляд sites.google.com/site_name.

Створення сайтів за допомогою Google Sites підпорядковується таким правилам:

- оформлення сайтів змінюється тільки по кольорах, розмірах та стилях шрифтів;

- заборона анонімних коментарів і втручання в зміст;

- відсутність стрічки RSS з оновленнями сайту.

Слід зазначити, що ці застереження для нашої роботи не принципові.

Оскільки дії по створенню сайтів Google Sites прості й докладно проінструктовані довідкою Google Sites Help, то ми не описуємо їх покроково. Разом з тим звертаємо увагу, що розробник сайту повинен бути зареєстрованим в Google, володіти акаунтом.

Для оформлення сайту доступні кілька шаблонів веб-дизайну, а саме:

- веб-сторінка - це сторінка для розміщення тексту тематичних розділів, зображень тощо;

- оголошення - сторінка для подачі текстових повідомлень, впорядкованих у хронологічному порядку, починаючи з останніх введених;

- картотека - сторінка для збереження посилань на завантажені файли, впорядкованих по папках;

- список - сторінка, на якій подаються структуровані дані як списки з кількох полів. 
Важливим є розташування сайту, який корисний не тільки для розробників, але й для користувачів. Обрання місця розташування - важливий крок, який дозволить адресно послуговуватися цікавою країнознавчою інформацією. Оскільки підготовче відділення Східноєвропейського національного університету імені Лесі Українки має власну сторінку, то було вирішено розмістити на ній посилання на новостворений сайт «Країнознавство від слухачівіноземців» (рис. 1). Відсилаємо користувачів до сайту https://sites.google.com/view/countrystudies/home, на якому вміщено зразок презентації слухача 2018-2019 навчального року Амаду Діалло (рис. 2, 3).

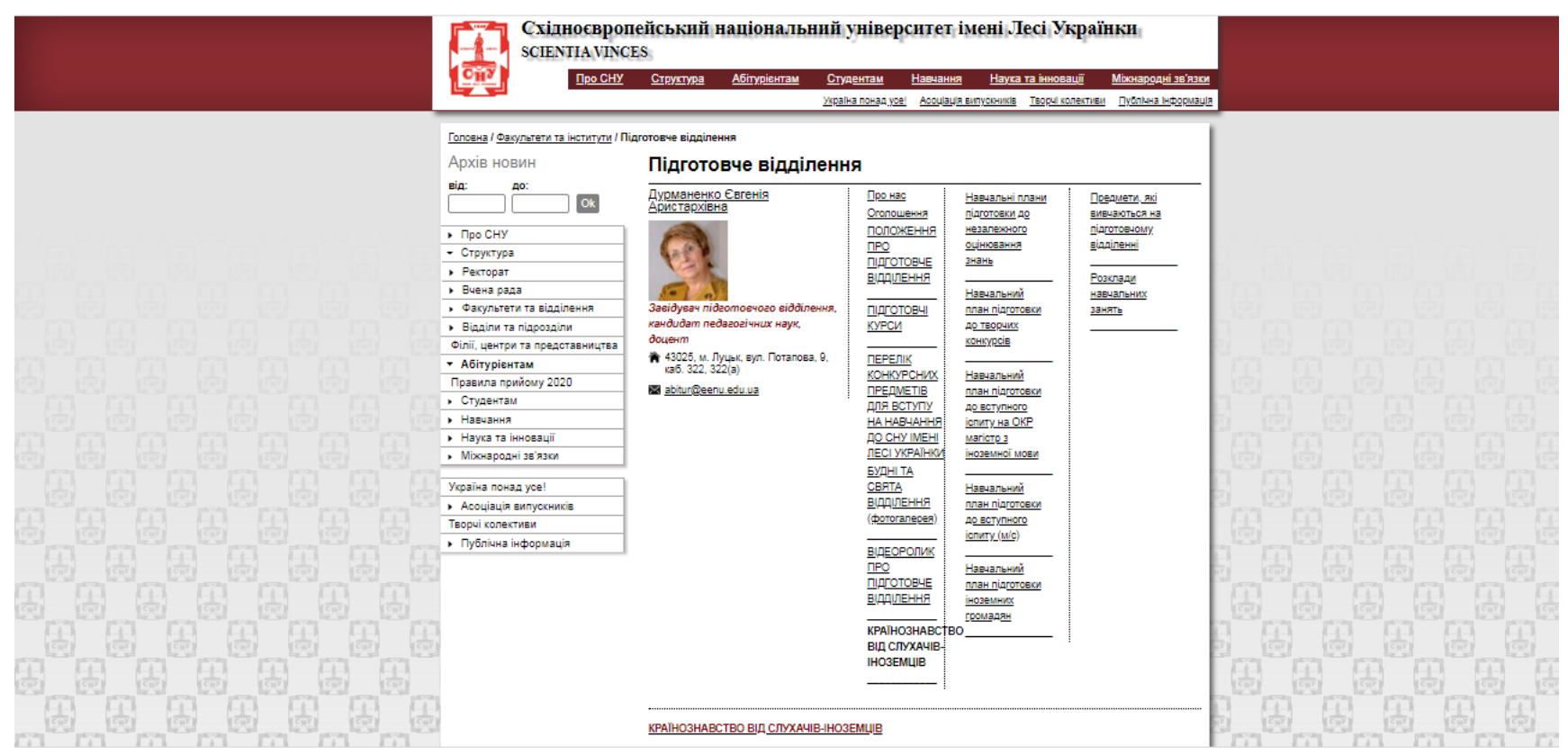

Рис. 1. Сторінка підготовчого відділення СНУ імені Лесі Українки

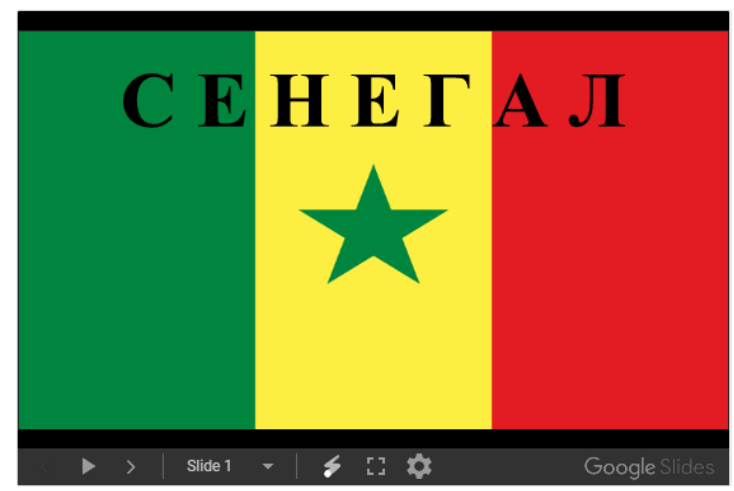

Рис. 2. Головна сторінка сайту, перший слайд презентації 


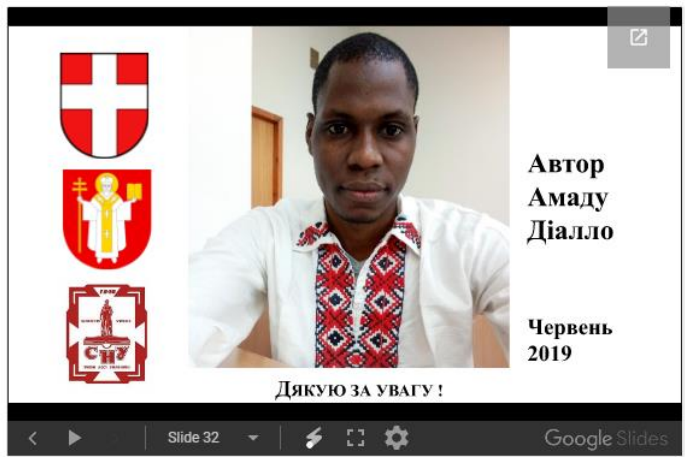

Рис. 3. Головна сторінка сайту, останній слайд презентації

Висновки та перспективи подальшого дослідження. Проведене дослідження дозволяє зробити такі висновки. По-перше, запропонована модель презентації виявилася продуктивною, оскільки порівняно невелика кількість слайдів містила коротку інформацію, яка супроводжувалася коментарем, дала адекватне уявлення про конкретну країну, викликала зацікавлення творців презентацій.

По-друге, під час підготовки презентації в Google Slides слухачі-іноземці під керівництвом викладачів опанували нову хмарну технологію.

По-третє, цьому сприяли технічні переваги, рушійною силою яких стала відсутність потрібного програмного забезпечення у слухачів, і зручності нової технології для них, обгрунтовані викладачами.

По-четверте, інтеграція різних додатків Google дала можливість створити засобами Google Sites сайт для розміщення презентацій про рідні країни слухачів-іноземців.

По-п’яте, створення сайту уможливить доступ до країнознавчої інформації широкого кола користувачів.

Перспективним напрямом подальшого дослідження $є$ наповнення сайту роботами майбутніх слухачів, створення на ньому різних тематичних сторінок із метою фіксації заключного етапу перевірки знань $з$ дисципліни «Українська мова як іноземна».

\section{Список бібліографічного опису}

1.Вступний курс з української мови для студентів-іноземців підготовчого відділення / за ред. Т. О. Дегтярьової. Суми : Університетська книга, 2010. - 415 с.

2.Гороть $€$. I. Notes on Ukrainian Grammar : навч.-метод. матеріали з граматики української мови для англомовних студентів-іноземців / Свгенія Гороть, Ніна Данилюк, Леся Малімон, Оксана Рогач. - Луцьк : СНУ імені Лесі Українки, 2014. - 40 с.

3.Данилюк Н. О. Українська мова як іноземна : робоча програма нормативної навчальної дисципліни для слухачівіноземців підготовчого відділення / Н. О. Данилюк, Т. Є. Масицька. - Луцьк : Вежа-Друк, 2017. - 24 с.

4.Кисельов Г. Д. Застосування хмарних технологій в дистанційному навчанні / Г. Д. Кисельов, К. В. Харченко //

Системный анализ и информационные технологии : XV международная научно-техническая конференция «САИТ-

2013», 27-31 мая 2013, Киев. - Киев : УНК «ИПСА» НТУУ «КПИ», 2013. - С. 351.

5.Лавріщева К. М. Індустріальний підхід до розробки і виконання прикладних систем в гетерогенних розподілених середовищах / К. М. Лавріщева, А. Ю. Стеняшин // International Conference «Parallel and Distributed Computing Systems», 13-14 березня 2013, Харків. - Харків, 2013. - С. 196-204.

6.Масицька Т. Є. Українська мова як іноземна : Комунікація / Тетяна Масицька. - Луцьк : Вежа-Друк, 2019. - 232 с.

7.Національна стратегія розвитку освіти в Україні на 2012-2021 роки // Директор школи, ліцею, гімназії. - 2011. № 6.

- С. $25-43$.

8.Сейдаметова 3. С. Облачные сервисы в образовании / 3. С. Сейдаметова, С. Н. Сейтвелиева // Информационные технологии в образовании. - 2011. - № 9. - С. 105-111. 
9.Туравініна О. М. Хмарні технології навчання студентів / О. М. Туравініна // Новітні комп’ютерні технології. 2012.

- № 10. - C. 119-121.

10. Хмарні обчислення [Електронний ресурс ]. Режим доступу: uk.wikipedia.org/wiki/Хмарні_обчислення.

11. Черняк Л. С. Интеграция - основа облака / Л. С. Черняк // Открытые системы. СУБД. - 2011. - № 7 , [Электронный

peсурс]. Режим доступа: http://www.osp.ru/os/2011/07/13010473/.

12. Широкова Е. А. Облачные технологии / Е. А. Широкова // Современные тенденции технических наук: материалы международной заочной научной конференции. - Уфа : Лето. - 2011. - С. 30-33.

13. Шишкіна М. П. Хмаро орієнтоване освітнє середовище навчального закладу: сучасний стан і перспективи розвитку

досліджень / М. П. Шишкіна, М. В. Попель // Інформаційні технології і засоби навчання. - 2013. - № 5 (37).

[Електронний ресурс]. Режим доступу: http://journal.iitta.gov.ua/index.php/itlt/article/view/903.

\section{References}

Sumy :

1. Vstupnyi kurs z ukrainskoi movy dlia studentiv-inozemtsiv pidhotovchoho viddilennia / za red. T. O. Dehtiarovoi. -

Universytetska knyha, 2010. - $415 \mathrm{~s}$.

2. Horot Ye. I. Notes on Ukrainian Grammar : navch.-metod. materialy $\mathrm{z}$ hramatyky ukrainskoi movy dlia anhlomovnykh studentiv-inozemtsiv / Yevheniia Horot, Nina Danyliuk, Lesia Malimon, Oksana Rohach. - Lutsk : SNU imeni Lesi Ukrainky, 2014. $-40 \mathrm{~s}$.

3. Danyliuk N. O. Ukrainska mova yak inozemna : robocha prohrama normatyvnoi navchalnoi dystsypliny dlia slukhachivinozemtsiv pidhotovchoho viddilennia / N. O. Danyliuk, T. Ye. Masytska. - Lutsk : Vezha-Druk, 2017. - 24 s.

4. Kyselov H. D. Zastosuvannia khmarnykh tekhnolohii v dystantsiinomu navchanni / H. D. Kyselov, K. V. Kharchenko // Sistemnyy analiz i informatsionnyye tekhnologii : XV mezhdunarodnaya nauchno-tekhnicheskaya konferentsiya «SAIT2013». 27-31 maya 2013. Kiyev. - Kiyev : UNK «IPSA» NTUU «KPI». 2013. - S. 351.

5. Lavrishcheva K. M. Industrialnyi pidkhid do rozrobky i vykonannia prykladnykh system $v$ heterohennykh rozpodilenykh seredovyshchakh / K. M. Lavrishcheva, A. Yu. Steniashyn // International Conference «Parallel and Distributed Computing Systems», 13-14 bereznia 2013, Kharkiv. - Kharkiv, 2013. - S. 196-204.

6. Masytska T. Ye. Ukrainska mova yak inozemna : Komunikatsiia / Tetiana Masytska. - Lutsk : Vezha-Druk, 2019. - 232

s.

7. Natsionalna stratehiia rozvytku osvity v Ukraini na 2012-2021 roky // Dyrektor shkoly, litseiu, himnazii. - 2011. - № 6. S. $25-43$.

8. Seydametova Z. S. Oblachnyye servisy v obrazovanii / Z. S. Seydametova. S. N. Seytveliyeva // Informatsionnyye tekhnologii v obrazovanii. - 2011. - № 9. - S. 105-111

9. Turavinina O. M. Khmarni tekhnolohii navchannia studentiv / O. M. Turavinina // Novitni kompiuterni tekhnolohii. 2012. - № 10. - C. 119-121.

10. Khmarni obchyslennia [Elektronnyi resurs ]. Rezhym dostupu: uk.wikipedia.org/wiki/Khmarni_obchyslennia.

11. Chernyak L. S. Integratsiya - osnova oblaka / L. S. Chernyak // Otkrytyye sistemy. SUBD. - 2011. - № 7. [Elektronnyy resurs]. Rezhim dostupa: http://www.osp.ru/os/2011/07/13010473/.

12. Shirokova E. A. Oblachnyye tekhnologii / E. A. Shirokova // Sovremennyye tendentsii tekhnicheskikh nauk: materialy mezhdunarodnoy zaochnoy nauchnoy konferentsii. - Ufa : Leto. - 2011. - S. 30-33. rozvytku

13. Shyshkina M. P. Khmaro oriientovane osvitnie seredovyshche navchalnoho zakladu: suchasnyi stan i perspektyvy

doslidzhen / M. P. Shyshkina, M. V. Popel // Informatsiini tekhnolohii i zasoby navchannia. - 2013. - № 5 (37). [Elektronnyi resurs ]. Rezhym dostupu : http://journal.iitta.gov.ua/index.php/itlt/article/view/903.

Стаття надійшла 20.02.2020 p. 